\title{
Bacterial identification of the vaginal microbiota in Ecuadorian pregnant teenagers: An exploratory analysis
}

\author{
Ana María Salinas ${ }^{1}$, Verónica Gabriela Osorio ${ }^{1}$, Pablo Francisco Endara ${ }^{1,2}$, Eduardo Ramiro Salazar ${ }^{3}$, \\ Gabriela Piedad Vasco $^{3}$, Sandra Guadalupe Vivero ${ }^{3}$, Antonio Machado ${ }^{\text {Corresp. }}{ }^{1}$ \\ 1 Instituto de Microbiología, Colegio de Ciencias Biológicas y Ambientales, Universidad San Francisco de Quito, Quito, Ecuador \\ 2 Colegio de Ciencias de la Salud, Universidad San Francisco de Quito, Universidad San Francisco de Quito, Quito, Ecuador \\ 3 Facultad de Ciencias Médicas, Universidad Central del Ecuador, Quito, Ecuador \\ Corresponding Author: Antonio Machado \\ Email address: amachado@usfq.edu.ec
}

Background: Bacterial vaginosis (BV) is a microbial imbalance (i.e. dysbiosis) that can produce serious medical effects in women at childbearing age. Little is known, however, about the incidence of BV or vaginal microbiota dysbiosis in pregnant teenagers in low and middle-income countries such as Ecuador. The scope of this exploratory analysis was to study the relationship between epidemiologic and microbial risk factors. Among the microbiology risk factors this study investigated five Lactobacillus species, two of them know in preview studies as microbiology risk factors for BV development (Lactobacillus acidophilus and Lactobacillus iners), and the last three known for being associated with a healthy vaginal tract (Lactobacillus crispatus, Lactobacillus gasseri and Lactobacillus jensenii). In addition, fastidious anaerobes known to be microbial risk factors for BV development in pregnant teenagers were searched as well, more exactly, Gardnerella vaginalis, Atopobium vaginae and Mobiluncus mulieris. Methods: Ninety-five healthy adolescent pregnant women, visiting a secondary level hospital in Quito - Ecuador, were enrolled into the study in 2015. The enrolled patients were between 10 to 13 weeks of pregnancy. Four epidemiological risk factors were collected in a survey: age, civil status, sexual partners and condom use. Also, vaginal pH was measured as a health risk factor. DNA was extracted from endocervical and exocervical epithelia from all the patients' samples. PCR analysis was performed in order to characterize the presence of the eight bacterial species known as risk factors for BV development, targeting three anaerobes and five Lactobacillus species. Univariate and multivariate analysis were performed to identify associated factors for the presence of anaerobic species using logistic regression. Results: The 95 vaginal microflora samples of these teenagers were analyzed. Two of the bacterial species known to cause BV: A. vaginae (100\%) and G. vaginalis (93.7\%) were found in high prevalence. Moreover, the most predominant bacterial Lactobacillus species found in the pregnant teenagers' vaginal tract were L. crispatus (92.6\%), L. iners $(89.5 \%)$ and $L$. 
acidophilus (87.4\%). In addition, the average vaginal $\mathrm{pH}$ measured in the study population was 5.2 , and high $\mathrm{pH}$ was associated with the presence of the three-anaerobic species ( $\mathrm{p}=$ 0.001 ). Finally, L. jensenii's presence in the study decreased in $72 \%$ the occupation of the three anaerobes. Discussion: This work identified a high $\mathrm{pH}$ as a risk factor for BV anaerobes' presence in adolescent pregnant women. Moreover, this study identified $L$. crispatus, $L$. iners and $L$. acidophilus to be the most abundant species in our study population. From all fastidious anaerobes analyzed in this study, A. vaginae was present in all pregnant teenagers. To conclude, $L$. jensenii could be a potential healthy vaginal microbiota candidate in pregnant teenagers and should be further analyzed in future studies. 
1 Bacterial Identification of the Vaginal Microbiota in Ecuadorian Pregnant Teenagers: An

2 Exploratory Analysis

3 Ana María Salinas ${ }^{1}$, Verónica Gabriela Osorio ${ }^{1}$, Pablo Francisco Endara ${ }^{1,2}$, Eduardo Ramiro

4 Salazar $^{3}$, Gabriela Piedad Vasco ${ }^{3}$, Sandra Guadalupe Vivero ${ }^{3}$ and Antonio Machado ${ }^{1}$

$5{ }^{1}$ Instituto de Microbiología, Universidad San Francisco de Quito, Quito, Pichincha, Ecuador

$6{ }^{2}$ Colegio de Ciencias de la Salud, Universidad San Francisco de Quito, Quito, Pichincha,

7 Ecuador

$8{ }^{3}$ Facultad de Ciencias Médicas, Universidad Central del Ecuador, Quito, Pichincha, Ecuador

9 Corresponding Author:

10 Antonio Machado ${ }^{1}$

11 Av. Diego de Robles y Vía Interoceánica, Quito, Pichincha, Ecuador

12 Email address: amachado@usfq.edu.ec 
13 Abstract

14 Background: Bacterial vaginosis (BV) is a microbial imbalance (i.e. dysbiosis) that can produce 15 serious medical effects in women at childbearing age. Little is known, however, about the 16 incidence of BV or vaginal microbiota dysbiosis in pregnant teenagers in low and middle-income 17 countries such as Ecuador. The scope of this exploratory analysis was to study the relationship between epidemiologic and microbial risk factors. Among the microbiology risk factors this study investigated five Lactobacillus species, two of them know in preview studies as microbiology risk factors for BV development (Lactobacillus acidophilus and Lactobacillus iners), and the last three known for being associated with a healthy vaginal tract (Lactobacillus crispatus, Lactobacillus gasseri and Lactobacillus jensenii). In addition, fastidious anaerobes known to be microbial risk factors for BV development in pregnant teenagers were searched as well, more exactly, Gardnerella vaginalis, Atopobium vaginae and Mobiluncus mulieris.

Methods: Ninety-five healthy adolescent pregnant women, visiting a secondary level hospital in Quito - Ecuador, were enrolled into the study in 2015. The enrolled patients were between 10 to 13 weeks of pregnancy. Four epidemiological risk factors were collected in a survey: age, civil status, sexual partners and condom use. Also, vaginal $\mathrm{pH}$ was measured as a health risk factor. DNA was extracted from endocervical and exocervical epithelia from all the patients' samples. PCR analysis was performed in order to characterize the presence of the eight bacterial species known as risk factors for BV development, targeting three anaerobes and five Lactobacillus species. Univariate and multivariate analysis were performed to identify associated factors for the presence of anaerobic species using logistic regression.

Results: The 95 vaginal microflora samples of these teenagers were analyzed. Two of the bacterial species known to cause BV: A. vaginae (100\%) and G. vaginalis $(93.7 \%)$ were found in high prevalence. Moreover, the most predominant bacterial Lactobacillus species found in the 
37 pregnant teenagers' vaginal tract were L. crispatus $(92.6 \%)$, L. iners $(89.5 \%)$ and L. acidophilus

38 (87.4\%). In addition, the average vaginal $\mathrm{pH}$ measured in the study population was 5.2, and high

$39 \mathrm{pH}$ was associated with the presence of the three-anaerobic species $(\mathrm{p}=0.001)$. Finally, $L$.

40 jensenii's presence in the study decreased in $72 \%$ the occupation of the three anaerobes.

41 Discussion: This work identified a high $\mathrm{pH}$ as a risk factor for BV anaerobes' presence in

42 adolescent pregnant women. Moreover, this study identified L. crispatus, $L$. iners and $L$.

43 acidophilus to be the most abundant species in our study population. From all fastidious

44 anaerobes analyzed in this study, A. vaginae was present in all pregnant teenagers. To conclude,

45 L. jensenii could be a potential healthy vaginal microbiota candidate in pregnant teenagers and

46 should be further analyzed in future studies. 
47

48 The bacterial microbiota of the vagina includes a diverse set of species (Ma, Forney \& Ravel,

49 2012), consisting of a balance between anaerobic and aerobic microorganisms (Alvarez-Olmos et

50 al., 2004). Commensal microorganisms in the vagina (vaginal microbiome) provide protection

51 against opportunistic and pathogenic bacteria, constituting the first line of defense against

52 invasive microorganisms (Ma, Forney \& Ravel, 2012; Romero et al., 2014).

53 Several species of Lactobacillus sp. are dominant members of the vaginal commensal barrier and

54 are usually associated with a healthy mucous membrane. Some of the species such as $L$.

55 crispatus, L. gasseri, L. jensenii among others contribute in lowering $\mathrm{pH}$ through the production

56 of great amounts of lactic acid and bactericide compounds (Wilks et al., 2004; Husain et al.,

57 2014), such as $\mathrm{H}_{2} \mathrm{O}_{2}$ and bacteriocins (Wilks et al., 2004; Kiss et al., 2007; Tamrakar et al., 2007;

58 Nelson et al., 2009; Machado et al., 2013; O’Hanlon, Moench \& Cone, 2013; Romero et al.,

59 2014). All these compounds and properties allow vaginal epithelial homeostasis and also keeping

60 away possible pathogenic bacteria. However not all Lactobacillus species found in the vaginal

61 tract are strong probiotic species because of their low bactericide elements production such as $L$.

62 acidophilus (Wilks et al., 2004), L. iners (Tamrakar et al., 2007) and others.

63 The vaginal microbiota of healthy women, during their reproductive age, is typically stable

64 (Romero et al., 2014). When a woman is pregnant, however, hormone levels fluctuate, causing

65 changes in the vaginal microbiota (Huang et al., 2014; Romero et al., 2014; MacIntyre et al.,

66 2015). This fluctuation can be even more dramatic in teenagers, who may be at an increased risk

67 for sexually transmitted diseases (STDs) and bacterial vaginosis (BV) (Alvarez-Olmos et al., 68 2004). In Ecuador, teenagers have a wide range of health care needs, in particular related to 
69 sexual and reproductive health, where the high rates of adolescent pregnancy and its health 70 control are a national concern (Goicolea, 2010; Loaiza \& Liang, 2013; Svanemyr et al., 2017).

$71 \mathrm{BV}$ is a condition in which the vaginal microbiota suffers a shift associated with a reduction in

72 several species of probiotic Lactobacillus and an increase in the presence of anaerobes ( $G$.

73 vaginalis, A. vaginae and Mobiluncus sp.). BV also causes an individual to be more susceptible

74 to STDs or suffer pre-term labor and late miscarriage (Wilks et al., 2004; Tamrakar et al., 2007;

75 Nelson et al., 2009; Romero et al., 2014; McMillan et al., 2015).

76 The vaginal microbiota in pregnant teenagers has been characterized in certain studies, however,

77 these studies are often conducted in high-income countries where hygiene conditions differ from

78 low-income countries (Kiss et al., 2007; Nelson et al., 2009; Verstraelen et al., 2009; Aagaard et

79 al., 2012; Huang et al., 2014; Husain et al., 2014; Hyman et al., 2014; Romero et al., 2014;

80 MacIntyre et al., 2015). There are few studies that have been conducted in low- and middle-

81 income countries (LMICs) such as Ecuador (Vaca et al., 2010) or Brazil (Ferreira et al., 2015),

82 yet those analyses relied only on Nugent scores (gram stained smears). This study was therefore

83 conducted to assess the presence of five Lactobacillus sp. (L. crispatus, L. gasseri, L. jensenii, L.

84 acidophilus and L. iners) and three bacterial anaerobes (A. vaginae, G. vaginalis and M. mulieris)

85 associated with BV in pregnant teenagers from Ecuador using PCR amplification of 16S and 23S

86 rRNA genes.

\section{Materials and Methods}

88 Study area, design and subject selection 
89 The study was carried out in a secondary level public hospital in Quito - Ecuador that serves as a

90 national reference hospital and teaching hospital, which provides care to pregnant women,

91 including family planning and postpartum support services (Moya, 2001). The hospital also

92 provides services for pregnant teenagers (most of them from Hispanic ethnicity), and in 2014,

93 2,230 pregnant teens received assistance (Ministerio de Salud Pública el Ecuador, 2014).

94 From September 2015 to November 2015, 95 pregnant teenage women (10-19 years old) were

95 enrolled into the study. The study population involved teenagers between 10 to 13 weeks

96 pregnant and reported to have not taken antimicrobials for the previous 3 months. The enrolled

97 patients were interviewed in a private room and survey included demographic and health

98 questions, including: age, marital status, number of sexual partners in the last year and the use of

99 preservatives (condoms) during intercourse. Applicants were excluded from the study if they

100 reported to have had sexual intercourse within the last 48 hours, or in case there was any

101 evidence of macroscopic cervical bleeding or placenta and fetal disease. This investigation

102 adopted a cross-sectional study design to determine the association between the presence of

103 Lactobacillus sp. and BV related anaerobes.

\section{Ethics statement}

105 Ninety-five volunteers met the eligibility criteria and read and signed the informed consent (if 18 106 or 19 years old) or had their parents or legal representative sign if they were less of 18 years old. 107 The Ethics Committee of the Central University of Ecuador approved this study (Protocol code: 108 cif-cv-fcm.1).

\section{Samples collection}

110 Vaginal samples were collected by trained gynecologists. The procedure began by removing the 111 cervical mucus with a sterile swab. Furthermore, endocervical and exocervical epithelia were 
112 gathered with a cervix examination brush (Rovers Medical Devices B.V.; Rovers ${ }^{\circledR}$ Cervex-

113 Brush () ). Additionally, the $\mathrm{pH}$ of the mucus samples was determined from the vaginal swab using

114 a pH test strip (MColorpHast, Merck-Millipore). The detachable head of the cervix examination

115 brush was preserved in a liquid vial (BD, BD SurePath ${ }^{\mathrm{TM}}$ liquid-based Pap test) and transported

116 under refrigeration conditions $\left(4^{\circ} \mathrm{C}\right)$. The samples were stored at $-40^{\circ} \mathrm{C}$ for $5 \mathrm{~h}$ until DNA 117 extraction.

118 DNA extraction

119 DNA from the vaginal brush was extracted by following commercial kit instructions 120 (NucleoSpin ${ }^{\circledR}$ Tissue 740952, Macherey-NagelTM, Düren-Germany) (Macherey-Nagel, 2014).

121 Briefly, the brush samples were placed in $1.5 \mathrm{ml}$ microtubes with $180 \mu 1$ Buffer $\mathrm{T} 1$ and $25 \mu 1$ 122 Proteinase $\mathrm{K}$. Then, to homogenate the mixture, the microtubes were centrifuged for $15 \mathrm{~s}$ at 1,500 $123 \mathrm{x} g$ and heated at room temperature for $5 \mathrm{~min}$. Next, the tubes were vortexed vigorously for $15 \mathrm{~s}$ 124 and span for $15 \mathrm{~s}$ at $1,500 \times \mathrm{g}$. The microtubes were then incubated for 10 minutes at $70^{\circ} \mathrm{C}$, and 125 followed by 5 minutes at $95^{\circ} \mathrm{C}$. The tubes were centrifuged again for $15 \mathrm{~s}$ at $1,500 \times \mathrm{g}$, after which $126200 \mu 1$ of Buffer B3 was added. Tubes were vortexed vigorously for 30 s and heated at $70^{\circ} \mathrm{C}$ for 10 127 minutes. Ethanol (96-100\%) was added to each sample and vigorously vortexed once more. A 128 Nucleospin ${ }^{\circledR}$ Tissue Column was placed into a collection tube and the sample was added to the 129 column. The tubes were then centrifuged for $1 \mathrm{~min}$ at $11,000 \mathrm{x} g$ and discarded and new ones were 130 placed under the column. Kit buffers (BW and B5) were added to the columns and centrifuged 131 for $1 \mathrm{~min}$ at $11,000 \times \mathrm{g}$ for each buffer. The columns were dried with another centrifugation and 132 finally DNA was eluted with buffer (BE) (Macherey-Nagel, 2014). The concentration of the extracted DNA was measured in a NANOVUE spectrophotometer (GE Healthcare Life Sciences)

134 to determine the DNA extraction quality. The original DNA extraction was then divided into two 135 diluted aliquots with Buffer BE to a final concentration of $20 \mathrm{ng} / \mu \mathrm{L}$. Finally, the remaining 
136 original samples were preserved at $-80^{\circ} \mathrm{C}$, as well as the two aliquots of $20 \mathrm{ng} / \mu \mathrm{L}$, were preserved 137 at $-20^{\circ} \mathrm{C}$ for Polymerase Chain Reaction (PCR) analysis.

\section{Polymerase Chain Reaction}

139 PCR amplification was performed for nine different primer sets, targeting three anaerobes and 140 five Lactobacillus species and one primer set for Lactobacillus genus of vaginal microbiota (see 141 Table 1). Samples of L. jensenii and A. vaginae were sequenced to confirm their identity due to 142 the lack of a strong specificity, while L. acidophilus, G. vaginalis and M. mulieris primer sets 143 showed a strong specificity and thus samples did not require a further sequencing confirmation. 144 The eventual confirmation step used the following universal primers for 16S rRNA sequencing (27Fw-AGA GTT TGA TCM TGG CTC AG and 805Rw-GAC TAC CAG GGT ATC TAA TC;

146 Temperature of annealing: $62{ }^{\circ} \mathrm{C}$; Tanner et al., 1999) through a PCR assay carried out with a 147 final volume of $50-\mu 1$ (adapted from the procedure below) and sent to Functional Biosciences, Inc 148 (Madison, WI, USA). The 16S rDNA sequences were compared to known sequences in GenBank 149 with the advanced gapped BLAST (basic local alignment search tool) algorithm (Camacho et al., 150 2009).

151 The PCR assays were performed with T100 ${ }^{\mathrm{TM}}$ thermal cycler (Bio-Rad Laboratories, USA) in a 152 reaction volume of $20 \mu \mathrm{L}$. The reaction mix included $4 \mu \mathrm{L} 5 \mathrm{X}$ Green GoTaq ${ }^{\circledR}$ Flexi Buffer 153 (Promega, USA), $2 \mu \mathrm{L} \mathrm{MgCl}_{2} 2.5 \mathrm{mM}$ (Promega, USA), 0.50 $\mu \mathrm{L}$ dNTP mix 10mM (Promega, 154 USA), $0.20 \mu \mathrm{L}$ GoTaq ${ }^{\circledR}$ Flexi DNA Polymerase (Promega, USA), $1.00 \mu \mathrm{L}$ of each primer $0,5 \mu \mathrm{M}$, $1552 \mu \mathrm{L}$ from each DNA sample and the remaining volume with molecular grade $\mathrm{H}_{2} \mathrm{O}$.

156 PCR amplification first cycle consisted in a pre-melt phase at $94^{\circ} \mathrm{C}$ for 2 min and then 157 denaturation at $94^{\circ} \mathrm{C}$ for 30 seconds. After that, annealing at each species temperature (see Table 
158 1) was realized for 30 seconds, and extension was performed at $72^{\circ} \mathrm{C}$ for 1 minute. This was 159 repeated for 29 more cycles to 31 for the bigger amplicons ( $>500 \mathrm{bp}$ ). An additional 5 min 160 extension was included at the end of the cycles to complete the extension of the primers. The 161 PCR products were visualized using electrophoresis in 2\% agarose gels and staining with 162 ethidium bromide $0.1 \%$, with negative and positive controls provided by the Microbiology 163 Institute at Universidad San Francisco de Quito.

\section{Statistical analysis}

165 Uni and multivariate analysis were realized in order to identify risk factors such as: age; civil 166 status; number of sexual partners; condom use; vaginal $\mathrm{pH}$; and Lactobacillus spp. associated 167 with the presence or absence of anaerobic species (i.e. outcome) using logistic regression. Most 168 variables were treated as categorical. For testing differences in the studied factors and vaginal 169 microbiota between the groups of patients, the study was defined by the presence of three 170 anaerobic species (A. vaginae, G. vaginalis and M. mulieris). Chi-square statistics were computed 171 and logistic regression was used to estimate odds ratios for association between studied factors on

172 the presence of three anaerobic species (A. vaginae, G. vaginalis and M. mulieris). Statistically 173 significant differences were assumed when P-values were equal or less than 0.05. Statistical 174 analyses were performed using STATA version 14.0.

Table 1: Primers used in this study.

\section{Results}

\section{Characteristics of study population}

178 Most of the study participants were between 16-17 years old (53.7\%) and non-married (68.4\%). 179 Approximately two thirds had only one sexual partner (76.8\%) and around half did not use 
180

181 182 183

condoms (52.6\%). In addition, all enrolled participants were from Hispanic ethnicity and nearly one third of the study population had a vaginal $\mathrm{pH}$ higher than five $(31.5 \%)$. The $\mathrm{pH}$ mean value found in this study group was of 5.2 with a standard deviation (SD) of 0.7 and an interval of 4-7, Table 2 provides descriptive statistics of the study population.

Table 2: Epidemiological characteristics of pregnant teenagers in this study.

\section{Commensal microbiota}

All samples showed the presence of Lactobacillus spp. The most frequently detected were $L$. crispatus 88/95 (92.6\%), L. iners 85/95 (89.5\%) and L. acidophilus 83/95 (87.4\%). While L. jensenii and L. gasseri were only found in $77 / 95(81.1 \%)$ and $54 / 95(56.8 \%)$ of the studied pregnant teenagers, respectively.

All study participants were colonized by at least two of the five Lactobacillus species, which were analyzed. The most frequent combination was L. crispatus and L. iners in $82.1 \%$. $L$. crispatus and L. acidophilus, were the second most prevalent combination with $80.0 \%$, respectively. Other types of combinations were less frequent: L. crispatus and L. jensenii (74.7\%); L. crispatus and L. gasseri (55.8\%); and L. crispatus, L. gasseri and L. jensenii (47.4\%), as shown in Figure 1.

Figure 1: Percentage of grouped Lactobacillus species found between the samples.

\section{BV associated anaerobes}


198 The main BV associated anaerobic bacteria found in our study population was A. vaginae (found 199 in $100 \%$ of the samples) followed by G. vaginalis and M. mulieris (in $93.7 \%$ and $34.7 \%$ of the 200 samples, respectively).

201 When we looked at the presence of anaerobic bacteria in combination with the presence of 202 Lactobacillus species, less than one-fifth of the samples had five Lactobacillus spp. and the three203 anaerobic species (17.5\%). Nevertheless, as showed in Figure 2, no statistical significance was 204 found for the association between the number of Lactobacillus species and the presence of three 205 anaerobic species (P-value for Fisher's exact test $>0.05$ ).

Figure 2: Percentage of teenagers with and without the presence of the three BV-associated anaerobes by the number of Lactobacillus species pre-existent in the vaginal epithelium.

208 Factors associated with presence of Gardnerella vaginalis, Atopobium vaginae and 209 Mobiluncus mulieris

210 In univariate analysis, higher $\mathrm{pH}$ was statistically associated with the presence of three anaerobes. 211 Having a $\mathrm{pH}$ higher than 5 increased the likelihood that three anaerobes would be present in the 212 samples (crude OR 4.7, 95\% CI: 1.82-12.3), as shown in Table 3. In contrast, the presence of $L$. 213 jensenii in vaginal microbiota was associated with a decreased presence of three-anaerobic 214 species (crude OR 0.28, 95\% CI: 0.1-0.81), as shown in Table 4.

215 Table 3: Factors associated with the presence or absence of three anaerobic bacterial species 216 (Gardnerella vaginalis, Atopobium vaginae and Mobiluncus mulieris) that are known to be 217 associated with bacterial vaginosis. 
218 Table 4: Association of Lactobacillus spp. with the presence or absence of three anaerobic

219 bacterial species (Gardnerella vaginalis, Atopobium vaginae and Mobiluncus mulieris) that are 220 known to be associated with bacterial vaginosis.

221 When the associations (Table 3) were adjusted for age, condom use and number of sexual

222 partners, the only significant factor associated with presence of three anaerobes was a high $\mathrm{pH}$ 223 (adjusted $\mathrm{OR}=5.5 ; 95 \% \mathrm{CI}$ : 2-15.2, P-value: 0.002). After adjusting for the same variables in 224 Table 4, the presence of $L$. jensenii remained to be associated with the absence of three anaerobes 225 (adjusted OR 0.16; 95\% CI: 0.04-0.6, P-value: 0.006).

\section{Discussion}

227 In the current study, we found that the genital tract of pregnant Ecuadorian teenagers was 228 colonized primarily by L. crispatus. All samples from the studied teenagers were positive for at 229 least one analyzed Lactobacillus species. Additionally, from the five-species analyzed in this 230 study, colonization by the consortium formed through L. crispatus, L. iners and L. acidophilus 231 was the most prevalent. These results coincide with previous reports indicating that Lactobacillus 232 species is the most abundant commensal bacteria found in healthy vaginal microbiota of pregnant and non-pregnant adult women in the world, as shown in Table 5 (Kiss et al., 2007; Tamrakar et

234 al., 2007; Verstraelen et al., 2009; Dominguez-Bello et al., 2010; Hernández-Rodríguez et al., 235 2011; Aagaard et al., 2012; Husain et al., 2014; Hyman et al., 2014; Romero et al., 2014; 236 MacIntyre et al., 2015; McMillan et al., 2015). However, it is important to mention that other 237 Lactobacillus species could have been present on the vaginal epithelium of these pregnant 238 teenagers because this study did not analyze every Lactobacillus species but only the most 
239 frequently cited in other studies (see Table 5). We found a large proportion of individuals 240 colonized by BV associated anaerobic bacteria, including: A. vaginae (100\%), and G. vaginalis 241 (93.7\%), which showed some discrepancies with previous studies carried out in adult women

242 (Table 5). The percentage of $A$. vaginae in this study was considerably different from other 243 published studies due to the presence of $A$. vaginae in $100 \%$ of the analyzed pregnant teenagers 244 in Ecuador. In agreement with the previous results, G. vaginalis was also found in more than $93 \%$ 245 of the pregnant teenagers. As referenced by previous studies, G. vaginalis and A. vaginae are the 246 main anaerobes associated with BV (Menard et al., 2008; Verstraelen \& Swidsinski, 2013;

247 Bretelle et al., 2015; Machado \& Cerca, 2015; Hardy et al., 2016).

248 Table 5: Summary of vaginal microbiota characterization studies in pregnant women (including 249 this study).

252 The association between having a certain commensal vaginal microbiota with a healthy 253 pregnancy outcome has been thoroughly studied in the past two decades (Kiss et al., 2007; 254 Nelson et al., 2009; Verstraelen \& Swidsinski, 2013). It has been postulated that an optimal 255 commensal microbiota in the vaginal epithelium reduces the risk of infections with any pathogen 256 (Trichomonas vaginalis, Neisseria gonorrhoeae, Chlamydia trachomatis, Candida sp., and 257 others) in the reproductive track and also seems to prevent preterm birth caused by bacterial 258 vaginosis (O’Hanlon, Moench \& Cone, 2013; Krauss-Silva et al., 2014). Several studies around 259 the world (see Table 5), such as in USA (Hyman et al., 2014; Romero et al., 2014), United 260 Kingdom (MacIntyre et al., 2015), Belgium (Verstraelen et al., 2009), China (Huang et al., 2014) 261 and Japan (Tamrakar et al., 2007), showed that the most abundant Lactobacillus species found in 262 pregnant women are L. iners, and L. crispatus. In agreement to this study, these two species were 
263 the most abundant lactobacilli found in pregnant teenagers in Ecuador. The third most abundant

264 Lactobacillus species found in this study was L. acidophilus, which has only been observed in 265 studies from Mexico (Hernández-Rodríguez et al., 2011) and USA (Hyman et al., 2014). In USA,

266 it has been encountered in non-pregnant teenager's vaginal microbiota with a prevalence of $49 \%$

267 (Alvarez-Olmos et al., 2004). L. acidophilus has not been analyzed or encountered in other 268 studies worldwide as shown in Table 5.

Other Lactobacillus species, such as L. jensenii and L. gasseri, are usually found in high percentages in other studies of vaginal microbiota present in pregnant women (Tamrakar et al., 272 2007; Verstraelen et al., 2009; Husain et al., 2014; Hyman et al., 2014; MacIntyre et al., 2015).

273 However, Lactobacillus species, such as L. delbruecki, L. rhamosus, L. reuteri, L. casei. L. 274 paracasei, L. vaginalis, L. coleohominis, L. fermentum, L. fornicalis, L. gallinarum, L. helveticus, 275 L. kefiranofaciens, L. kitasatonis, and L. ultunensis, have been analyzed as well but are not 276 commonly found in studies of pregnant women's vaginal microbiota (Hyman et al., 2014). 277 Nonetheless, L. jhonsonii was detected by 16S rRNA pyrosequencing characterization of vaginal 278 microbiota in pregnant women in USA (Aagaard et al., 2012), although this species was not 279 analyzed in the current study. Therefore, a more extensive analysis may be necessary in the 280 future.

Atopobium vaginae was the most frequent anaerobe observed in vaginal microbiota from pregnant teenagers in our study (Table 5), and it has been detected in USA (Hyman et al., 2014; 283 Romero et al., 2014), Mexico (Hernández-Rodríguez et al., 2011), China (Huang et al., 2014), 284 Europe (Bretelle et al., 2015; MacIntyre et al., 2015) and Africa (McMillan et al., 2015). This 285 anaerobe is usually found in association with G. vaginalis and M. mulieris (Hernández-Rodríguez 286 et al., 2011) in the development of BV (Verstraelen \& Swidsinski, 2013). As similar as G. 
287 vaginalis, A. vaginae is usually found in minor percentages around the world (Nelson et al., 2009;

288 Dominguez-Bello et al., 2010; Huang et al., 2014; Romero et al., 2014; MacIntyre et al., 2015).

289 The percentage of $A$. vaginae in this study was markedly different from other published studies.

290 In our study, $A$. vaginae was present in $100 \%$ of the analyzed pregnant teenagers in Ecuador. In

291 agreement with previous results, G. vaginalis was also found in more than 93\% of pregnant

292 teenagers. Although this study did not quantify the abundance of G. vaginalis or A. vaginae, the

293 prevalence of these anaerobes is not concordant with the normal prevalence in healthy pregnant

294 women in other studies (Nelson et al., 2009; Dominguez-Bello et al., 2010; Huang et al., 2014;

295 Romero et al., 2014), such as Africa where 66.7\% of healthy pregnant women had G. vaginalis

296 (Nelson et al., 2009) or the USA where 2.2\% of healthy pregnant women had G. vaginalis or A.

297 vaginae (Romero et al., 2014), which is low in comparison with the results from this study.

298 Finally, only $34.5 \%$ of the pregnant teenagers were positive for M. mulieris, which is high in 299 comparison to other studies performed in pregnant women such as $2.0 \%$ in Mexico (Hernández300 Rodríguez et al., 2011), 0.37\% in Rwanda (Tchelougou et al., 2013) and 18.2\% in USA (Waters et 301 al., 2008).

302 The major drawback of this study was the lack of quantitative data which may allow us to assess 303 the status of the colonization of the distinct bacterial taxa. However, BV is a very common cause 304 for high $\mathrm{pH}$ in the vagina, associated with the shifting of microbiota from protective 305 Lactobacillus sp. to anaerobes, such as G. vaginalis and A. vaginae (De Backer et al., 2007). 306 When this occurs, the $\mathrm{pH}$ rises from 4.2 that is considered normal to 4.5 or higher, which is now 307 used as a positive indicator for BV (O'Hanlon, Moench \& Cone, 2013). The pH in pregnant 308 women has been analyzed in several studies, such as China (Huang et al., 2014) and Rwanda 309 (McMillan et al., 2015) where the pH media was 4.5 and 4.6, respectively. In this study, however, 310 the observed $\mathrm{pH}$ was 5.2, which is a marker for the shift in dominance from Lactobacillus to 
311 anaerobic microbiota on the vaginal epithelium. The presence of the three anaerobes analyzed in 312 this study appeared to increase the vaginal $\mathrm{pH}$, which is in agreement with other studies 313 (McMillan et al., 2015; Donders et al., 2016) that evaluated the establishment of BV in women.

314 This exploratory study was able to characterize the heterogeneity of the commensal 315 Lactobacillus species in these pregnant teenagers, where all study participants had more than one 316 Lactobacillus species colonizing the vagina. As shown in Figure 2, the reproductive track of our 317 study participants revealed two to five Lactobacillus species. Even though there is no statistical 318 significance with the absence or presence of the three anaerobes, our results differed from what 319 was published in other studies (Hernández-Rodríguez et al., 2011; Hyman et al., 2014). In 320 Mexico, it has been reported that the vagina was colonized by one to four species (Hernández321 Rodríguez et al., 2011), meanwhile in the USA by one to two species (Hyman et al., 2014). $L$. 322 crispatus, L. gasseri and L. jensenii (Wilks et al., 2004; Husain et al., 2014) are known as strong 323 beneficial species, however L. acidophilus (Wilks et al., 2004), and L. iners (Tamrakar et al., 324 2007) are known as weaker protective species. Therefore, the high prevalence of these two 325 species in the vaginal microbiota could partially explain the high prevalence of $A$. vaginae and $G$. 326 vaginalis in Ecuadorian pregnant teenagers. Even without a statistical difference, the high 327 prevalence of $L$. iners and L. acidophilus could imply some sort of bewilderment in the 328 commensal bacteria of the vaginal microbiota, which could allow the proliferation of anaerobic 329 bacteria. Further study is necessary to quantify each Lactobacillus species and anaerobic bacteria 330 in each sample in order to determine the exact load of the detected vaginal microbiota in pregnant 331 teenagers. Also, the amount of the beneficial substances produced by Lactobacillus species found 332 in Ecuadorian women, such as $\mathrm{H}_{2} \mathrm{O}_{2}$ or lactic acid, should be quantified to determine their 333 protective ability. 
334 Finally, this study limitations were principally caused by the low number of samples, and the lack 335 of bacterial abundance detection.

\section{Conclusion}

337 Our study identified $L$. crispatus, L. iners and L. acidophilus to be the most abundant species in 338 our study population of pregnant teenagers. L. jensenii could be a potential microbiota protective 339 candidate in the vaginal microbiota in pregnant Ecuadorian teenagers. Meanwhile, A. vaginae, G. 340 vaginalis and $M$. mulieris were found in $100 \%, 93.7 \%$ and $34.7 \%$ of the analyzed pregnant 341 teenagers, respectively.

342 To the authors' knowledge, this is the first study of vaginal microbiota in pregnant teenagers in 343 Ecuador. Furthermore, this investigation was only realized in pregnant teenagers and there was no 344 control group (non-pregnant teenagers). Further studies are necessary in pregnant women to 345 quantify the main Lactobacillus species and also the BV associated anaerobes identified in this 346 pilot study, as well as, to statistical determine a possible correlation with preterm birth or BV in 347 Ecuadorian pregnant women, which it was not possible to characterize in this exploratory study.

349 List of abbreviations

350 BV: Bacterial vaginosis

351 STDs: Sexually Transmitted Diseases

352 LMICs: Low and Middle-Income Countries 


\section{Availability of data and material}

354 See additional database in supplementary files (Additional file 1)

\section{Acknowledgments}

356 We thank Jay Graham, Gabriel Trueba and Sonia Zapata for their valuable contributions to the 357 manuscript, the volunteers that made possible this study, also the people who work in the Institute 358 of Microbiology of USFQ, in particular a Dario Cueva who helped in validation of L. jensenii 359 primers and the staff from Biomedicine Centre of the Central University for their help and 360 support.

\section{References}

Aagaard K., Riehle K., Ma J., Segata N., Mistretta T-AA., Coarfa C., Raza S., Rosenbaum S., van den Veyver I., Milosavljevic A., Gevers D., Huttenhower C., Petrosino J., Versalovic J. 2012. Metagenomic Approach to Characterization of the Vaginal Microbiome Signature in Pregnancy. PLoS ONE 7. DOI: 10.1371/journal.pone.0036466.

Alvarez-Olmos MI., Barousse MM., Rajan L., Van Der Pol BJ., Fortenberry D., Orr D., Fidel PL. 2004. Vaginal lactobacilli in adolescents: presence and relationship to local and systemic immunity, and to bacterial vaginosis. Sexually transmitted diseases 31:393-400. DOI: 10.1097/01.OLQ.0000130454.83883.E9.

De Backer E., Verhelst R., Verstraelen H., Alqumber MA., Burton JP., Tagg JR., Temmerman M., Vaneechoutte M. 2007. Quantitative determination by real-time PCR of four vaginal Lactobacillus species, Gardnerella vaginalis and Atopobium vaginae indicates an inverse relationship between L. gasseri and L. iners. BMC Microbiol 7:115. DOI: 1471-2180-7-115 [pii] $\backslash r 10.1186 / 1471-2180-7-115$. 
375 Bretelle F., Rozenberg P., Pascal A., Favre R., Bohec C., Loundou A., Senat MV., Aissi G.,

376 Lesavre N., Brunet J., Heckenroth H., Luton D., Raoult D., Fenollar F. 2015. High

377 Atopobium vaginae and Gardnerella vaginalis vaginal loads are associated with preterm

378 birth. Clinical Infectious Diseases 60:860-867. DOI: 10.1093/cid/ciu966.

379 Byun R., Nadkarni MA., Chhour K-L., Martin FE., Jacques NA., Hunter N. 2004. Quantitative

380 analysis of diverse Lactobacillus species present in advanced dental caries. Journal of

381 Clinical Microbiology 42:3128-36. DOI: 10.1128/JCM.42.7.3128-3136.2004.

382 Camacho C., Coulouris G., Avagyan V., Ma N., Papadopoulos J., Bealer K., Madden TL. 2009.

383 BLAST plus: architecture and applications. BMC Bioinformatics 10:1. DOI: Artn 421 $\backslash \mathrm{nDoi}$

$384 \quad 10.1186 / 1471-2105-10-421$.

385 Dominguez-Bello MG., Costello EK., Contreras M., Magris M., Hidalgo G., Fierer N., Knight R.

386 2010. Delivery mode shapes the acquisition and structure of the initial microbiota across

387 multiple body habitats in newborns. Proceedings of the National Academy of Sciences

$388 \quad$ 107:11971-11975. DOI: 10.1073/pnas.1002601107.

Donders G., Gonzaga A., Marconi C., Donders F., Michiels T., Eggermont N., Bellen G., Lule J., Byamughisa J. 2016. Increased vaginal pH in Ugandan women: What does it indicate? European Journal of Clinical Microbiology and Infectious Diseases 35:1297-1303. DOI: 10.1007/s10096-016-2664-2.

Ferreira CST., Marconi C., Parada CM de LG., Duarte MTC., Gonçalves APO., Rudge MVC., Silva MG da. 2015. Bacterial vaginosis in pregnant adolescents: proinflammatory cytokine and bacterial sialidase profile. Cross-sectional study. São Paulo Medical Journal 133:46570. DOI: $10.1590 / 1516-3180.2014 .9182710$.

Fredricks DN., Fiedler TL., Thomas KK., Oakley BB., Marrazzo JM. 2007. Targeted PCR for detection of vaginal bacteria associated with bacterial vaginosis. Journal of Clinical Microbiology 45:3270-3276. DOI: 10.1128/JCM.01272-07. 
400 Garg KB., Ganguli I., Das R., Talwar GP. 2009. Spectrum of Lactobacillus species present in 401 healthy vagina of Indian women. Indian Journal of Medical Research 129:652-657.

402 Goicolea I. 2010. Adolescent pregnancies in the Amazon Basin of Ecuador: a rights and gender

Henriques A., Cereija T., Machado A., Cerca N. 2012. In silico vs in vitro analysis of primer specificity for the detection of Gardnerella vaginalis, Atopobium vaginae and Lactobacillus spp. BMC research notes 5:637. DOI: 10.1186/1756-0500-5-637.

Hernández-Rodríguez C., Romero-González R., Albani-Campanario M., Figueroa-Damián R., Meraz-Cruz N., Hernández-Guerrero C. 2011. Vaginal microbiota of healthy pregnant mexican women is constituted by four lactobacillus species and several vaginosis-associated bacteria. Infectious Diseases in Obstetrics and Gynecology 2011. DOI: $10.1155 / 2011 / 851485$

Huang Y-E., Wang Y., He Y., Ji Y., Wang L-P., Sheng H-F., Zhang M., Huang Q-T., Zhang D-J., Wu J-J., Zhong M., Zhou H-W. 2014. Homogeneity of the vaginal microbiome at the cervix, posterior fornix, and vaginal canal in pregnant Chinese women. Microbial ecology 69:40714. DOI: $10.1007 / \mathrm{s} 00248-014-0487-1$.

Husain SM., Wilks M., Mupita M., Reddy SP., Hennessy EM., Macfarlane AJ., Millar MR. 2014. Diversity and stability of cultured vaginal lactobacilli in pregnant women from a multiethnic urban UK population. Journal of Applied Microbiology 117:258-265. DOI: 
425 Hyman RW., Fukushima M., Jiang H., Fung E., Rand L., Johnson B., Vo KC., Caughey AB., 426 Hilton JF., Davis RW., Giudice LC. 2014. Diversity of the vaginal microbiome correlates 427 with preterm birth. Reproductive sciences (Thousand Oaks, Calif.) 21:32-40. DOI: 10.1177/1933719113488838.

Kiss H., Kögler B., Petricevic L., Sauerzapf I., Klayraung S., Domig K., Viernstein H., Kneifel W. 2007. Vaginal Lactobacillus microbiota of healthy women in the late first trimester of pregnancy. BJOG: An International Journal of Obstetrics and Gynaecology 114:1402-1407.

Ma B., Forney LJ., Ravel J. 2012. Vaginal microbiome: rethinking health and disease. Annual

Loaiza E., Liang M. 2013. ADOLESCENT PREGNANCY: A Review of the Evidence. UNFPA. review of microbiology 66:371-89. DOI: 10.1146/annurev-micro-092611-150157.

Machado A., Almeida C., Salgueiro D., Henriques A., Vaneechoutte M., Haesebrouck F., Vieira MJ., Rodrigues L., Azevedo NF., Cerca N. 2013. Fluorescence in situ Hybridization method using Peptide Nucleic Acid probes for rapid detection of Lactobacillus and Gardnerella spp. BMC microbiology 13:82. DOI: 10.1186/1471-2180-13-82.

Machado A., Cerca N. 2015. Influence of Biofilm Formation by Gardnerella vaginalis and Other Anaerobes on Bacterial Vaginosis. The Journal of infectious diseases 212:1856-61. DOI: 10.1093/infdis/jiv338.

Macherey-Nagel. 2014. Genomic DNA from Tissue, User manual, NucleoSpin®Tissue. :40. MacIntyre DA., Chandiramani M., Lee YS., Kindinger L., Smith A., Angelopoulos N., Lehne B., 
450 Arulkumaran S., Brown R., Teoh TG., Holmes E., Nicoholson JK., Marchesi JR., Bennett

451 PR. 2015. The vaginal microbiome during pregnancy and the postpartum period in a

$452 \quad$ European population. Scientific reports 5:8988. DOI: 10.1038/srep08988.

453 McMillan A., Rulisa S., Sumarah M., Macklaim JM., Renaud J., Bisanz JE., Gloor GB., Reid G.

454 2015. A multi-platform metabolomics approach identifies highly specific biomarkers of

455 bacterial diversity in the vagina of pregnant and non-pregnant women. Scientific reports

$456 \quad$ 5:14174. DOI: $10.1038 /$ srep14174.

457 Menard J-P., Fenollar F., Henry M., Bretelle F., Raoult D. 2008. Molecular quantification of

458 Gardnerella vaginalis and Atopobium vaginae loads to predict bacterial vaginosis. Clinical

459 infectious diseases : an official publication of the Infectious Diseases Society of America

$460 \quad 47: 33-43$. DOI: $10.1086 / 588661$.

461 Ministerio de Salud Pública el Ecuador. 2014. PACIENTES EFECTIVAMENTE ATENDIDAS EN

462 HOSPITALIZACIÓN (Informe de Rendición de Cuentas 2014). Quito.

463 Moya W. 2001.HISTORIA DEL HOSPITAL GINECO OBSTÉTRICO ISIDRO AYORA.

464 Available at http://www.hgoia.gob.ec/index.php/hospital (accessed January 23, 2017).

465 Nelson DB., Hanlon A., Hassan S., Britto J., Geifman-Holtzman O., Haggerty C., Fredricks DN.

466 2009. Preterm labor and bacterial vaginosis-associated bacteria among urban women.

467 Journal of Perinatal Medicine 37:130-134. DOI: 10.1515/JPM.2009.026.

468 O’Hanlon DE., Moench TR., Cone RA. 2013. Vaginal pH and microbicidal lactic acid when

469 lactobacilli dominate the microbiota. PLoS ONE 8. DOI: 10.1371/journal.pone.0080074.

470 Romero R., Hassan SS., Gajer P., Tarca AL., Fadrosh DW., Bieda J., Chaemsaithong P., Miranda

471 J., Chaiworapongsa T., Ravel J. 2014. The vaginal microbiota of pregnant women who

472 subsequently have spontaneous preterm labor and delivery and those with a normal delivery

473 at term. Microbiome 2:18. DOI: 10.1186/2049-2618-2-18.

474 Svanemyr J., Guijarro S., Riveros BB., Chandra-Mouli V. 2017. The health status of adolescents 
475 in Ecuador and the country's response to the need for differentiated healthcare for 476 adolescents. Reproductive Health 14:29. DOI: 10.1186/s12978-017-0294-5.

477 Tamrakar R., Yamada T., Furuta I., Cho K., Morikawa M., Yamada H., Sakuragi N., Minakami H. 478 2007. Association between Lactobacillus species and bacterial vaginosis-related bacteria, 479 and bacterial vaginosis scores in pregnant Japanese women. BMC infectious diseases 7:128. $480 \quad$ DOI: $10.1186 / 1471-2334-7-128$.

481 Tanner MA., Shoskes D., Shahed A., Pace NR. 1999. Prevalence of corynebacterial 16S rRNA 482 sequences in patients with bacterial and "nonbacterial" prostatitis. Journal of Clinical $483 \quad$ Microbiology 37:1863-1870.

484 Tchelougou D., Karou DS., Kpotsra A., Balaka A., Assih M., Bamoke M., Katawa G., Anani K., 485 Simpore J., de Souza C. 2013. Infections vaginales chez les femmes enceintes au centre 486 hospitalier régional de Sokodé (Togo) entre 2010 et 2011. Medecine et Sante Tropicales $487 \quad 23: 49-54$. DOI: $10.1684 / \mathrm{mst} .2013 .0142$.

488 Tsai CC., Lai CH., Yu B., Tsen HY. 2010. Use of PCR primers and probes based on the 23S 489 rRNA and internal transcription spacer (ITS) gene sequence for the detection and enumerization of Lactobacillus acidophilus and Lactobacillus plantarum in feed

$491 \quad$ supplements. Anaerobe 16:270-277. DOI: 10.1016/j.anaerobe.2010.01.003.

492 Vaca M., Guadalupe I., Erazo S., Tinizaray K., Chico ME., Cooper PJ., Hay P. 2010. High

493 prevalence of bacterial vaginosis in adolescent girls in a tropical area of Ecuador. BJOG: An $494 \quad$ International Journal of Obstetrics and Gynaecology 117:225-228. DOI: 10.1111/j.1471$495 \quad$ 0528.2009.02397.x.

496 Verstraelen H., Swidsinski A. 2013. The biofilm in bacterial vaginosis: implications for 497 epidemiology, diagnosis and treatment. Current opinion in infectious diseases 26:86-9.

$498 \quad$ DOI: $10.1097 /$ QCO.0b013e32835c20cd.

499 Verstraelen H., Verhelst R., Claeys G., De Backer E., Temmerman M., Vaneechoutte M. 2009. 
500 Longitudinal analysis of the vaginal microflora in pregnancy suggests that L. crispatus

501 promotes the stability of the normal vaginal microflora and that L. gasseri and/or L. iners are

502 more conducive to the occurrence of abnormal vaginal microflora. BMC microbiology

503 9:116. DOI: $10.1186 / 1471-2180-9-116$.

504 Waters TP., Denney JM., Mathew L., Goldenberg RL., Culhane JF. 2008. Longitudinal trajectory

505 of bacterial vaginosis during pregnancy. American Journal of Obstetrics and Gynecology

506 199. DOI: 10.1016/j.ajog.2008.06.061.

507 Wilks M., Wiggins R., Whiley A., Hennessy E., Warwick S., Porter H., Corfield A., Millar M.

508 2004. Identification and H2O2 Production of Vaginal Lactobacilli from Pregnant Women at

509 High Risk of Preterm Birth and Relation with Outcome. Journal of Clinical Microbiology

$510 \quad$ 42:713-717. DOI: 10.1128/JCM.42.2.713-717.2004.

511 Zhang R., Daroczy K., Xiao B., Yu L., Chen R., Liao Q. 2012. Qualitative and semiquantitative

512 analysis of Lactobacillus species in the vaginas of healthy fertile and postmenopausal

513 Chinese women. Journal of Medical Microbiology 61:729-739. DOI:

$514 \quad 10.1099 / \mathrm{jmm} .0 .038687-0$. 
Figure 1 (on next page)

Percentage of grouped Lactobacillus species found between the samples. 
100

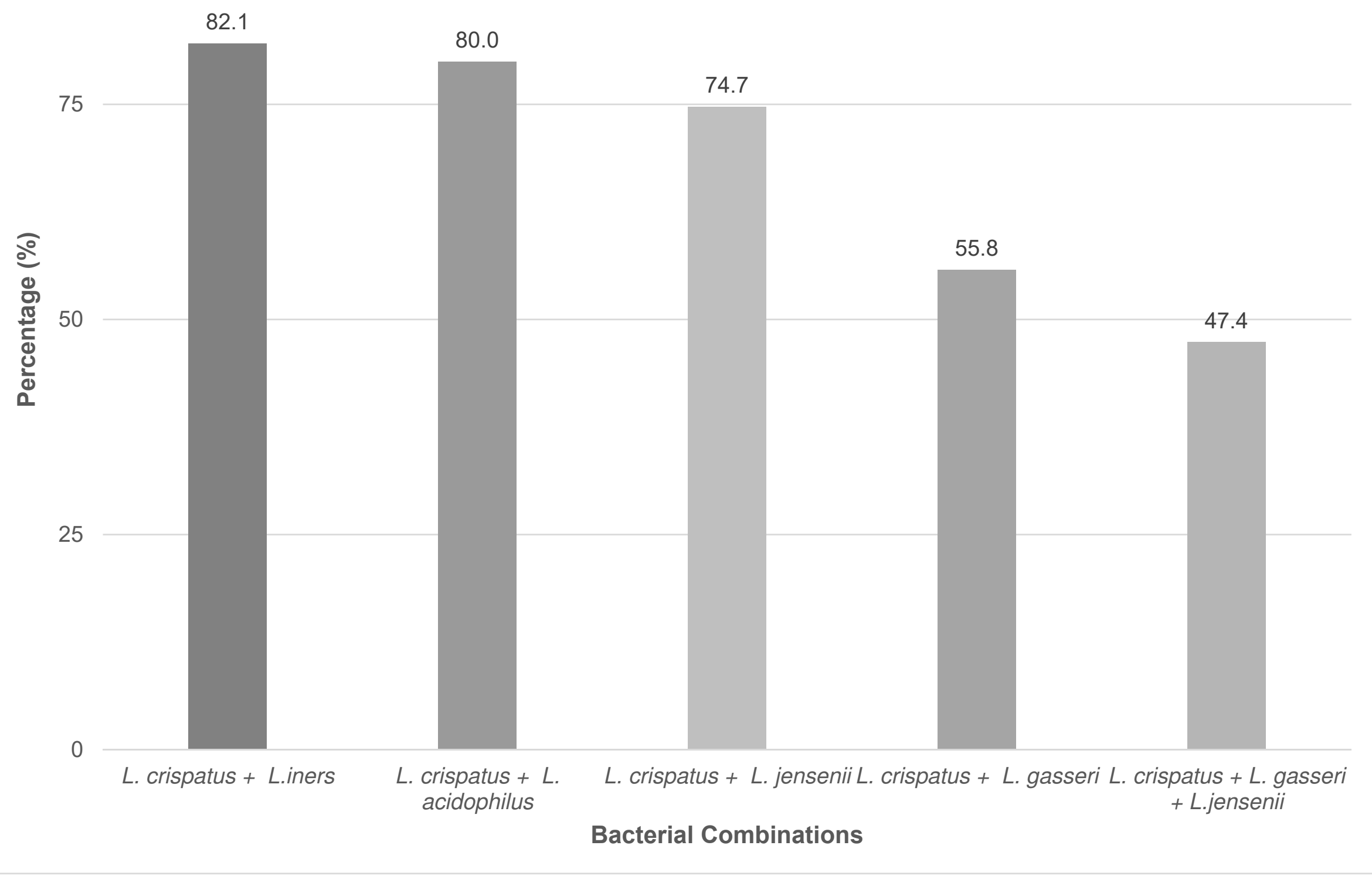




\section{Figure 2 (on next page)}

Percentage of teenagers with and without the presence of the three BV-associated anaerobes by the number of Lactobacillus species pre-existent in the vaginal epithelium.

Presence or absence of three anaerobic species by number of Lactobacillus species. 


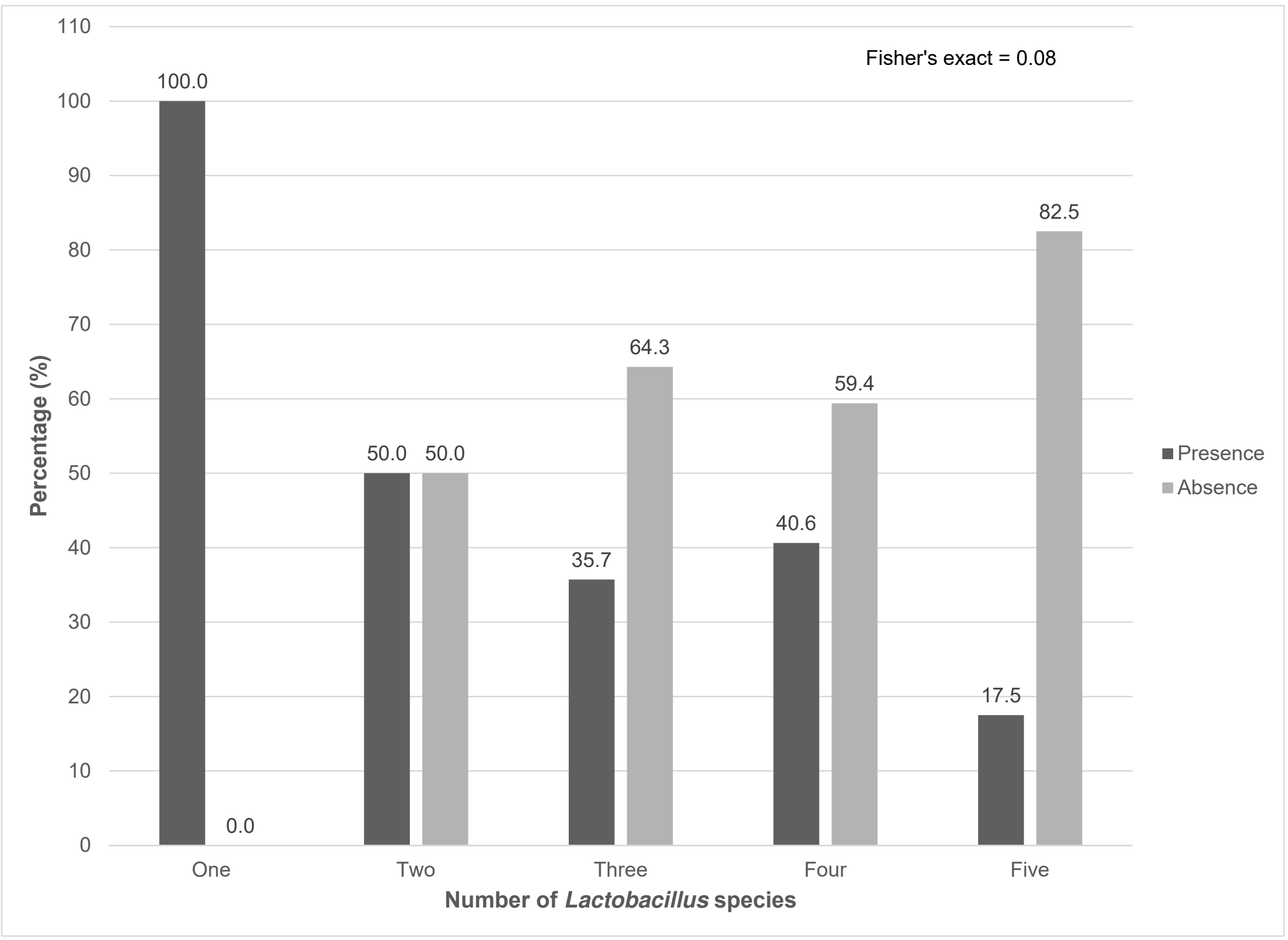


Table $\mathbf{1}$ (on next page)

Primers used in this study. 
Table 1: Primers used in this study

\begin{tabular}{|c|c|c|c|c|c|c|c|c|c|c|}
\hline Set & Name & Sequence $\left(5^{\prime}-3^{\prime}\right)$ & Target & $\begin{array}{c}\mathrm{T}\left({ }^{\circ} \mathrm{C}\right) \text { of } \\
\text { annealing }\end{array}$ & $\begin{array}{c}\text { Size of } \\
\text { fragment }\end{array}$ & Target & $\begin{array}{c}\text { Specificity } \\
\%\end{array}$ & $\begin{array}{l}\text { Cross reaction } \\
\text { with } \\
\text { microorganisms }\end{array}$ & Validation & Reference \\
\hline \multirow{2}{*}{1} & LactoF & TGGAAACAGRTGCTAATACCG & \multirow{2}{*}{$\begin{array}{l}\text { Lactobacillus } \\
\text { spp. }\end{array}$} & \multirow{2}{*}{$55^{\circ} \mathrm{C}$} & \multirow{2}{*}{$233 \mathrm{bp}$} & \multirow{2}{*}{ 16S rRNA } & \multirow{2}{*}{$100 \%$} & \multirow{2}{*}{ Negative } & \multirow{2}{*}{\begin{tabular}{|l|} 
Samples \\
sequenced to \\
confirm identity
\end{tabular}} & \multirow{2}{*}{$\begin{array}{l}\text { (Byun et al., } \\
\text { 2004; Zhang et } \\
\text { al., 2012) }\end{array}$} \\
\hline & LactoR & GTCCATTGTGGAAGATTCCC & & & & & & & & \\
\hline \multirow{2}{*}{2} & LinersF & GTCTGCCTTGAAGATCGG & \multirow{2}{*}{ L. iners } & \multirow{2}{*}{$55^{\circ} \mathrm{C}$} & \multirow{2}{*}{$158 \mathrm{bp}$} & \multirow{2}{*}{ 16S rRNA } & \multirow{2}{*}{$100 \%$} & \multirow{2}{*}{ Negative } & \multirow{2}{*}{\begin{tabular}{|l|} 
Samples \\
sequenced to \\
confirm identity
\end{tabular}} & \multirow{2}{*}{$\begin{array}{l}\text { (De Backer et } \\
\text { al., 2007; Zhang } \\
\text { et al., 2012) }\end{array}$} \\
\hline & LinersR & ACAGTTGATAGGCATCATC & & & & & & & & \\
\hline \multirow{2}{*}{3} & LcrispatusF & TTACTTCGGTAATGACGTTA & \multirow{2}{*}{ L. crispatus } & \multirow{2}{*}{$55^{\circ} \mathrm{C}$} & \multirow{2}{*}{$966 \mathrm{bp}$} & \multirow{2}{*}{ 16S rRNA } & \multirow{2}{*}{$100 \%$} & \multirow{2}{*}{ Negative } & \multirow{2}{*}{$\begin{array}{l}\text { Samples } \\
\text { sequenced to } \\
\text { confirm identity }\end{array}$} & \multirow{2}{*}{$\begin{array}{l}\text { (De Backer et } \\
\text { al., 2007; Zhang } \\
\text { et al., 2012) }\end{array}$} \\
\hline & LcrispatusR & GGAACTTTGTATCTCTACAA & & & & & & & & \\
\hline \multirow{2}{*}{4} & LgasseriF & TCGAGCGAGCTTGCCTAGATGAA & \multirow{2}{*}{ L. gasseri } & \multirow{2}{*}{$60^{\circ} \mathrm{C}$} & \multirow{2}{*}{$372 \mathrm{bp}$} & \multirow{2}{*}{ 16S rRNA } & \multirow{2}{*}{$100 \%$} & \multirow{2}{*}{$n / d$} & Samples & (Zhang et al., \\
\hline & LgasseriR & CGCGGCGTTGCTCCATCAGA & & & & & & & $\begin{array}{l}\text { sequenced to } \\
\text { confirm identity }\end{array}$ & 2012) \\
\hline & LjenseniiF & AGTCGAGCGAGCTTGCCTATAGAAG & & & & & & & Samples & (Garg et al., \\
\hline 5 & LactoR & GTCCATTGTGGAAGATTCCC & L. jensenii & $57^{\circ} \mathrm{C}$ & $342 \mathrm{bp}$ & 16S rRNA & $100 \%$ & Negative & $\begin{array}{l}\text { sequenced to } \\
\text { confirm identity } \\
\text { in this study }\end{array}$ & $\begin{array}{l}\text { 2009; Zhang et } \\
\text { al., 2012) }\end{array}$ \\
\hline 6 & LA-1 Fw & TCAATCAAAGGAAGACGCAG & $I$ a aidonhilus & $56^{\circ} \mathrm{C}$ & $221 \mathrm{hn}$ & $23 \mathrm{~S} \mathrm{rPNA}$ & $100 \%$ & Nocotiun & $n / d$ & (Tsai et al., \\
\hline $1^{0}$ & LA-2 Rw & CGCTCGCAATTTCGCTTA & L. aclaopnilus & $50^{\circ} \mathrm{C}$ & $221 \mathrm{op}$ & 23S rRNA & $100 \%$ & Negative & $\mathrm{n} / \mathrm{d}$ & 2010) \\
\hline 7 & Gard154-Fw & CTCTTGGAAACGGGTGGTAA & Gardnerella & $60^{\circ} \mathrm{C}$ & $301 \mathrm{bn}$ & $16 \mathrm{SrRNA}$ & $100 \%$ & Negative & $\mathrm{n} / \mathrm{d}$ & (Henriques et \\
\hline 1 & Gard154-Rv & TTGCTCCCAATCAAAAGCGGT & vaginalis & D & $3010 \mathrm{dp}$ & IOS IRINA & 10070 & Negative & $11 / \mathrm{U}$ & al., 2012) \\
\hline & Mobil-577F & GCTCGTAGGTGGTTCGTCGC & & & & & & & & \\
\hline 8 & \begin{tabular}{|l|} 
M.mulie- \\
1026R \\
\end{tabular} & CCACACCATCTCTGGCATG & $\begin{array}{l}\text { Mobluncus } \\
\text { mulieris }\end{array}$ & $62{ }^{\circ} \mathrm{C}$ & $449 \mathrm{bp}$ & 16S rRNA & $100 \%$ & Negative & $n / d$ & 2007) \\
\hline & Atop109-Fw & GAGTAACACGTGGGCAACCT & & & & & $16.7 \%$ & 5 from 6 & $\begin{array}{l}\text { Samples } \\
\text { sequenced to }\end{array}$ & \\
\hline 9 & Atop109-Rv & CCGTGTCTCAGTCCCAATCT & $\begin{array}{l}\text { Atopobium } \\
\text { vaginae }\end{array}$ & $62{ }^{\circ} \mathrm{C}$ & $221 \mathrm{bp}$ & 16S rRNA & $37.5 \%$ & 15 from 24 & $\begin{array}{l}\text { confirm identity } \\
\text { in this study }\end{array}$ & al., 2012) \\
\hline
\end{tabular}

\section{N/d - non determined}




\section{Table 2 (on next page)}

Epidemiological characteristics of pregnant teenagers in this study. 
Table 2: Epidemiological characteristics of pregnant teenagers in this study.

\begin{tabular}{|c|c|c|}
\hline \multicolumn{3}{|l|}{ Epidemiological Data } \\
\hline & $\mathrm{N}^{\circ}$ & $\%$ \\
\hline \multicolumn{3}{|l|}{ Age } \\
\hline 12 to 15 years & 18 & 19.0 \\
\hline 16 to 17 years & 51 & 53.7 \\
\hline 18 to 19 years & 26 & 27.4 \\
\hline \multicolumn{3}{|l|}{ Civil status } \\
\hline Single & 65 & 68.4 \\
\hline Free union & 29 & 30.5 \\
\hline Married & 1 & 1.1 \\
\hline \multicolumn{3}{|l|}{ Sexual partners } \\
\hline One & 73 & 76.8 \\
\hline More than one & 22 & 23.2 \\
\hline \multicolumn{3}{|l|}{ Condom use } \\
\hline No & 50 & 52.6 \\
\hline Sometimes (Occasionally, yes) & 45 & 47.4 \\
\hline \multicolumn{3}{|l|}{ Vaginal pH } \\
\hline 4 to 5 & 63 & 68.5 \\
\hline 6 to 7 & 29 & 31.5 \\
\hline
\end{tabular}

2 


\section{Table 3(on next page)}

Factors associated with the presence or absence of three anaerobic bacterial species (Gardnerella vaginalis, Atopobium vaginae and Mobiluncus mulieris) that are known to be associated with bacterial vaginosis. 
1 Table 3: Factors associated with the presence or absence of three anaerobic bacterial species

2 (Gardnerella vaginalis, Atopobium vaginae and Mobiluncus mulieris) that are known to be associated with bacterial vaginosis

\begin{tabular}{|c|c|c|c|c|c|}
\hline & Absent & Present & P-value & OR & P-value \\
\hline \multicolumn{6}{|l|}{ Age } \\
\hline 12 to 15 years & $10(15.4)$ & $8(26.7)$ & & 1 & \\
\hline 16 to 17 years & $34(52.3)$ & $17(56.7)$ & & $0.62(0.21-1.87)$ & 0.400 \\
\hline 18 to 19 years & $21(32.3)$ & $5(16.7)$ & 0.21 & $0.3(0.08-1.14)$ & 0.078 \\
\hline \multicolumn{6}{|l|}{ Civil status } \\
\hline Single & $44(67.7)$ & $21(70)$ & & 1 & \\
\hline Free union & $20(30.8)$ & $9(30)$ & & $0.94(0.37-2.42)$ & 0.900 \\
\hline Married & $1(1.5)$ & $0(0.0)$ & 0.99 & - & \\
\hline \multicolumn{6}{|l|}{ Condom use } \\
\hline No & $33(50.8)$ & $17(56.7)$ & & 1 & \\
\hline $\begin{array}{l}\text { Sometimes } \\
\text { (occasionally, yes) }\end{array}$ & $32(49.2)$ & $13(43.3)$ & 0.59 & $0.79(0.33-1.88)$ & 0.593 \\
\hline \multicolumn{6}{|l|}{ Sexual partners } \\
\hline One & 48 (73.9) & $25(83.3)$ & & 1 & \\
\hline More than one & $17(26.1)$ & $5(16.7)$ & 0.31 & $0.56(0.19-1.71)$ & 0.312 \\
\hline \multicolumn{6}{|l|}{ pH } \\
\hline 4 to 5 & $50(79.4)$ & $13(44.8)$ & & 1 & \\
\hline 6 to 7 & $13(20.6)$ & $16(55.2)$ & 0.001 & $4.7(1.82-12.3)$ & 0.001 \\
\hline
\end{tabular}

4

5 


\section{Table 4 (on next page)}

Association of Lactobacillus spp. with the presence or absence of three anaerobic bacterial species (Gardnerella vaginalis, Atopobium vaginae and Mobiluncus mulieris) that are known to be associated with bacterial vaginosis. 
1 Table 4: Association of Lactobacillus spp. with the presence or absence of three anaerobic

2 bacterial species (Gardnerella vaginalis, Atopobium vaginae and Mobiluncus mulieris) that are

3

4

\begin{tabular}{|c|c|c|c|c|c|}
\hline & Absent & Present & P-value & OR & P-value \\
\hline \multicolumn{6}{|c|}{ Bacterial species } \\
\hline \multicolumn{6}{|c|}{ Lactobacillus sp. } \\
\hline Absence & $(0.0)$ & $0(0.0)$ & & 1 & \\
\hline Presence & $65(100.0)$ & $30(100.0)$ & & does not apply & \\
\hline \multicolumn{6}{|c|}{ Lactobacillus iners } \\
\hline Absence & $6(9.2)$ & $4(13.3)$ & & 1 & \\
\hline Presence & $59(90.8)$ & $26(86.7)$ & 0.54 & $0.66(0.17-2.5)$ & 0.547 \\
\hline \multicolumn{6}{|c|}{ Lactobacillus crispatus } \\
\hline Absence & $4(6.1)$ & $3(10)$ & & 1 & \\
\hline Presence & $61(93.9)$ & $27(90)$ & 0.51 & $0.59(0.12-2.8)$ & 0.509 \\
\hline \multicolumn{6}{|c|}{ Lactobacillus gasseri } \\
\hline Absence & $25(38.5)$ & $16(53.3)$ & & 1 & \\
\hline Presence & $40(61.5)$ & $14(46.7)$ & 0.17 & $0.55(0.23-1.3)$ & 0.176 \\
\hline \multicolumn{6}{|c|}{ Lactobacillus jensenii } \\
\hline Absence & $8(12.3)$ & $10(33.3)$ & & 1 & \\
\hline Presence & $57(87.7)$ & $20(66.6)$ & 0.01 & $0.28(0.1-0.81)$ & 0.02 \\
\hline \multicolumn{6}{|c|}{ Lactobacillus acidophilus } \\
\hline Absence & $6(9.2)$ & $6(20)$ & & 1 & \\
\hline Presence & $59(90.8)$ & $24(80)$ & 0.14 & $0.41(0.12-1.38)$ & 0.151 \\
\hline
\end{tabular}

5

6

7 women/state; Nd - Not detected. 


\section{Table 5 (on next page)}

Summary of vaginal microbiota characterization studies in pregnant women (including this study). 
1

Table 5: Summary of vaginal microbiota characterization studies in pregnant women (including this study)

\begin{tabular}{|c|c|c|c|c|c|c|c|c|c|c|c|c|c|c|c|c|}
\hline \multirow[b]{2}{*}{$\mathbf{N}^{\circ}$} & \multirow[b]{2}{*}{$\begin{array}{l}\text { Population } \\
\text { Description }\end{array}$} & \multirow[b]{2}{*}{$\begin{array}{c}\text { Study } \\
\text { Group } \\
(n)\end{array}$} & \multirow[b]{2}{*}{ Place } & \multirow[b]{2}{*}{ Methodology } & \multirow[b]{2}{*}{$\underset{\text { (mean) }}{\mathrm{pH}}$} & \multicolumn{10}{|c|}{ Bacterial species detected (\%) } & \multirow[b]{2}{*}{ Author } \\
\hline & & & & & & $\begin{array}{c}\text { Lactobacillus } \\
\text { sp. }\end{array}$ & L. iners & $\begin{array}{c}L . \\
\text { crispatus } \\
\end{array}$ & L. acidophilus & L. jensenii & L. gasseri & $\begin{array}{c}G . \\
\text { vaginalis } \\
\end{array}$ & $\begin{array}{c}\text { A. } \\
\text { vaginae }\end{array}$ & $\begin{array}{c}\text { M. } \\
\text { mulieris }\end{array}$ & $\begin{array}{c}\text { Other } \\
\text { Lactobacillus } \\
\text { sp. }\end{array}$ & \\
\hline 1 & \begin{tabular}{|l|}
$\begin{array}{l}\text { Pregnant women (Age } \\
\text { range 18-35) }\end{array}$ \\
\end{tabular} & 126 & Austria & $\begin{array}{c}\text { Multiplex PCR by } \\
\text { Culture }\end{array}$ & $\mathrm{Nd}$ & 57.1 & $\mathrm{Nd}$ & 19.8 & $\mathrm{Nd}$ & 11.9 & $\mathrm{Nd}$ & $\mathrm{Nd}$ & $\mathrm{Nd}$ & $\mathrm{Nd}$ & YES & \begin{tabular}{|c|} 
(Kiss et al., \\
2007) \\
\end{tabular} \\
\hline 2 & $\begin{array}{l}\begin{array}{l}\text { Pregnant women (Age } \\
\text { range Nd) }\end{array} \\
\end{array}$ & 100 & Belgium & tRFLP - PCR & $\mathrm{Nd}$ & $\mathrm{X}$ & 40.3 & 23.4 & $\mathrm{Nd}$ & 3.9 & 40.3 & $\mathrm{Nd}$ & $\mathrm{Nd}$ & $\mathrm{Nd}$ & NO & \begin{tabular}{|l} 
(Verstraelen \\
et al., 2009)
\end{tabular} \\
\hline 3 & $\begin{array}{l}\text { Pregnant and non- } \\
\text { pregnant women (Age } \\
\text { range 19.4-39.2) }\end{array}$ & 34 & China & $\begin{array}{l}\text { PCR and } 16 \text { s region } \\
\text { sequencing }\end{array}$ & 4.5 & $\mathrm{x}$ & 55 & 26.9 & $\mathrm{Nd}$ & $\mathrm{Nd}$ & 6.3 & 11.8 & 11.8 & $\mathrm{Nd}$ & NO & $\begin{array}{l}\text { (Huang et } \\
\text { al., 2014) }\end{array}$ \\
\hline 4 & $\begin{array}{l}\text { Pregnant teenagers } \\
\text { (Age range 12-19) }\end{array}$ & 95 & Ecuador & $\begin{array}{c}\text { PCR } \\
\text { Electrophoresis gel } \\
\end{array}$ & 5.2 & 100 & 89.5 & 92.6 & 87,4 & 48.4 & 56.8 & 93.7 & 100 & 34.7 & NO & $\begin{array}{l}\text { This study } \\
\text { (2016) }\end{array}$ \\
\hline 5 & $\begin{array}{l}\begin{array}{l}\text { Pregnant women (Age } \\
\text { range 19-44) }\end{array} \\
\end{array}$ & 132 & Japan & $\begin{array}{l}\text { PCR } \\
\text { Culture } \\
\end{array}$ & $\mathrm{Nd}$ & 98.5 & 41.7 & 51.5 & $\mathrm{Nd}$ & 25 & 31.8 & $\mathrm{Nd}$ & $\mathrm{Nd}$ & $\mathrm{Nd}$ & NO & $\begin{array}{r}\text { (Tamrakar } \\
\text { et al., 2007) } \\
\end{array}$ \\
\hline 6 & $\begin{array}{l}\begin{array}{l}\text { Pregnant women (Age } \\
\text { range 13-43) }\end{array} \\
\end{array}$ & 140 & Mexico & PCR (DGGE) & $\mathrm{Nd}$ & 98.4 & 56.7 & $\mathrm{Nd}$ & 78,1 & $\mathrm{Nd}$ & 20.3 & $\mathrm{Nd}$ & $\mathrm{Nd}$ & 2.0 & YES & $\begin{array}{c}\text { (Hernández- } \\
\text { Rodríguez et } \\
\text { al., 2011) } \\
\end{array}$ \\
\hline 7 & $\begin{array}{l}\text { Pregnant and non- } \\
\text { pregnant women (Age } \\
\text { range 18-55) }\end{array}$ & 131 & Rwanda & $\begin{array}{c}165 \text { region } \\
\text { pyrosequencing }\end{array}$ & 4.6 & $\mathrm{x}$ & $\mathrm{x}$ & $\mathrm{x}$ & $\mathrm{Nd}$ & $\mathrm{x}$ & $\mathrm{x}$ & $\mathrm{x}$ & $\mathrm{x}$ & $\mathrm{Nd}$ & NO & $\begin{array}{r}\text { (McMillan } \\
\text { et al., 2015) } \\
\end{array}$ \\
\hline 8 & $\begin{array}{l}\begin{array}{l}\text { Pregnant women (Age } \\
\text { range Nd) }\end{array} \\
\end{array}$ & 42 & $\begin{array}{c}\text { United } \\
\text { Kingdom }\end{array}$ & $\begin{array}{c}16 \text { region } \\
\text { pyrosequencing }\end{array}$ & $\mathrm{Nd}$ & $\mathrm{X}$ & $30^{*}$ & $43^{*}$ & $\mathrm{Nd}$ & $14^{*}$ & 9* & $\mathrm{Nd}$ & $2^{*}$ & $\mathrm{Nd}$ & YES & $\begin{array}{r}\text { (MacIntyre } \\
\text { et al., 2015) } \\
\end{array}$ \\
\hline 9 & $\begin{array}{l}\begin{array}{l}\text { Pregnant women (Age } \\
\text { range 28-31) }\end{array} \\
\end{array}$ & 293 & $\begin{array}{c}\text { United } \\
\text { Kingdom } \\
\end{array}$ & $\begin{array}{c}\text { Culture } \\
\text { MALDI-TOF }\end{array}$ & $\mathrm{Nd}$ & 75 & $\mathrm{Nd}$ & 37 & $\mathrm{Nd}$ & 45 & 34 & $\mathrm{Nd}$ & $\mathrm{Nd}$ & $\mathrm{Nd}$ & YES & $\begin{array}{l}\text { (Husain et } \\
\text { al., 2014) }\end{array}$ \\
\hline 10 & $\begin{array}{l}\text { Pregnant and non- } \\
\text { pregnant women (Age } \\
\text { range Nd) }\end{array}$ & 54 & USA & $\begin{array}{c}165 \text { region } \\
\text { pyrosequencing }\end{array}$ & $\mathrm{Nd}$ & $\mathrm{x}$ & $58.5^{*}$ & $38.1^{*}$ & $\mathrm{Nd}$ & $\mathrm{x}$ & $4.3^{*}$ & $2.2^{*}$ & $2.2^{*}$ & $\mathrm{Nd}$ & YES & $\begin{array}{l}\text { (Romero et } \\
\text { al., 2014) }\end{array}$ \\
\hline 11 & $\begin{array}{l}\text { Pregnant and non- } \\
\text { pregnant women (Age } \\
\text { mean } 31,4 \text { ) }\end{array}$ & 84 & USA & $\begin{array}{c}165 \text { region } \\
\text { pyrosequencing }\end{array}$ & $\mathrm{Nd}$ & $\mathrm{x}$ & $\mathrm{x}$ & $\mathrm{x}$ & $\mathrm{Nd}$ & $\mathrm{X}$ & $\mathrm{Nd}$ & $\mathrm{Nd}$ & $\mathrm{Nd}$ & $\mathrm{Nd}$ & YES & $\begin{array}{l}\text { (Aagaard et } \\
\text { al., 2012) }\end{array}$ \\
\hline 12 & $\begin{array}{l}\text { Pregnant women (Age } \\
\geq 18 \text { ) }\end{array}$ & 88 & USA & $\begin{array}{c}\text { PCR } \\
\text { Sanger sequencing }\end{array}$ & $\mathrm{Nd}$ & $\mathrm{x}$ & \begin{tabular}{|c|} 
76.9 African \\
21.7 Asian \\
23.1 \\
Caucasian \\
68.4 Hispanic \\
\end{tabular} & \begin{tabular}{|c}
30.8 African \\
41.5 \\
Cacasian \\
15.8 Hispanic
\end{tabular} & $\begin{array}{c}21,7 \text { Asian } \\
1,5 \text { Caucasian }\end{array}$ & \begin{tabular}{|c|}
7.7 African \\
27.7 \\
Cacasian \\
31.6 \\
Hispanic \\
\end{tabular} & \begin{tabular}{|c|}
7.7 African \\
17.4 Asian \\
41.5 \\
Caucasian \\
10.5 \\
Hispanic \\
\end{tabular} & $\mathrm{Nd}$ & $\mathrm{x}$ & $\mathrm{Nd}$ & YES & $\begin{array}{l}\text { (Hyman et } \\
\text { al., 2014) }\end{array}$ \\
\hline 13 & $\begin{array}{l}\begin{array}{l}\text { Pregnant women (Age } \\
\text { mean 24) }\end{array} \\
\end{array}$ & 50 & USA & ${ }_{\mathrm{q}}^{\mathrm{PCR}}$ & $\mathrm{Nd}$ & $\mathrm{Nd}$ & $\mathrm{Nd}$ & $\mathrm{X}$ & $\mathrm{Nd}$ & $\mathrm{Nd}$ & $\mathrm{Nd}$ & 66.7 & $\mathrm{Nd}$ & $\mathrm{Nd}$ & NO & $\begin{array}{l}\text { (Nelson et } \\
\text { al., 2009) }\end{array}$ \\
\hline 14 & $\begin{array}{l}\text { Pregnant women (Age } \\
\text { range 21-33) }\end{array}$ & 9 & Venezuela & $\begin{array}{c}\text { PCR } \\
\text { Pyrosequencing }\end{array}$ & $\mathrm{Nd}$ & 88-94 & $\mathrm{Nd}$ & $\mathrm{Nd}$ & $\mathrm{Nd}$ & $\mathrm{Nd}$ & $\mathrm{Nd}$ & $0.1-2$ & 4-34 & $\mathrm{Nd}$ & NO & $\begin{array}{l}\text { (Dominguez- } \\
\text { Bello et al.) }\end{array}$ \\
\hline
\end{tabular}

